\title{
Creative Transposition of Puppet's Movement as Cultural Identity Case Study 'Setan Jawa’ Film By Garin Nugroho
}

\author{
Agustina Kusuma Dewi ${ }^{1}$, Yasraf Amir Piliang ${ }^{2}$, Irfansyah ${ }^{3}$, Acep Iwan Saidi ${ }^{4}$ \\ ${ }_{1,2,3,4}$ Faculty of Visual Art and Design, InstitutTeknologi Bandung, Indonesia \\ 19austinakusumadewi.3881@gmail.com, ${ }^{2}$ yasraf2000@yahoo.com, ${ }^{3}$ fandkv@yahoo.co.id, \\ 4acepiwan@fsrd.itb.ac.id
}

\begin{abstract}
Image in film is language that can be understood when the image were moving. 'Movement' is a change of position on a body of the initial balance point. Acceleration technologies positioning 'movement' became important keywords that need to be presented in each communication channel. 'Setan Jawa' Film by Garin Nugroho (2016) is black and white silent film, which the gamelan orchestra composed by Rahayu Supanggah. On 'Setan Jawa' Film, 'movement' being the narrative visual sign in the various arts - including puppet - a vehicle for constructing sign of 'movement' as cultural identity. Focusing on the Javanese identity refers to the result of research by Roger Long (1979), using a narrative visual approach, case study and analysis of documentation, this study aims to identify form of creative transposition puppet's movement in 'Setan Jawa' Film as cultural identity. Result of the study conclude that creative transposition on 'Setan Jawa' Film which constructed based on several types of movement adapted from Roger Long (1979)'s research-there are kadhak, mukadhiphuh and kathentheng-meaning should be considered in order to represent gesture as specific nonverbal message in relation on its context. It's not only showing the surface of cultural narration, but also representation of transcendental meaning.
\end{abstract}

Keywords: setan jawa film, cultural identity, creative transposition, cultural code, inter-semiotic

\section{INTRODUCTION}

Through the movie, change the style of social interaction in Indonesian society can now be presented in real images that offer knowledge and cultural understanding deeper, especially with regard to understanding the visual language used by people in Indonesia to convey the concept of self and the concept of cultural value system to identify the identity a person in a particular ethnic group. Human understanding to a movie happens because the pictures are arranged sequentially. Within this framework the film creates its own reality, regardless of what people think about the basic reality in which we live [1]. In the sense that the film is not a complete replication or mimesis of everyday reality that we face, but it creates its own reality. 
Cultural identity is a feeling (emovemental significance) of a person to co-owns (sense of belonging) or is affiliated with a particular culture [3]. Society was divided into groups and then identify the culture, namely that everyone considers themselves as representatives of a particular culture. Imagery is viewed as a visual symbol that is placed into a language that institutionalize meaning through a system of differences. Subjects were viewed to be understood and to be in a certain social position, in which this position will form the parameters are very open to interpretation. Efforts are underway in the read operation was seen here as a social practice. Not only in regards external sociological space in which the subject sees a place to stay, but also their subjective capacity.

Cultural identity often refers to the definition of ethnic groups, a group formed by kinship as the primary core of social relations that has its convention [4]; have the values and the same culture, and conscious of the sense of togetherness in a form of culture, communications network and the interaction itself, and characterize their group that received by other groups and can be distinguished from other population groups. Thus, the Cultural Identity in question in this research is the otherness that are fluid and can change; formation is a continuous effort that is the result of the parties who are in a particular definition of identity in society in perpetuating narratives about themselves so as to form a continuous feeling of continuity biographical; which is characterized by certain symbols that are used to mark the existence of the cultural identity.

Taking the mythological narrative Pesugihan Kandang Bubrah, this film tells the story of a transition situation that occurred at the beginning of the 20th century in the order of the Java community, 'Setan Jawa' Garin Nugroho is a black and white film with cinematic-orchestra approach that separates the picture and sound, accompanied by a gamelan orchestra Rahayu Supanggah's work was first released in 2016, and until 2020 was scheduled to tour around the world. The visual narration built on the film, including actors gestural, transposed into medium 'movement' puppet creatively. In this case, it is assumed that the movement which appears on the surface can be formed from cultural identityt' tacit knowledge, because in social practices, 'self' in the culture continues to move into perceptions and memory recollection collection- over time. [5] There are several researcher doing research on motion and/or movement in psychological area, but 'movement' as cultural identity has not been developed in many research, especially in visual art and design area, focusing on intersemiotic' process as sign's transposition.

In Javanese culture, various kinds of movement puppets, will determine the type of character and personality of the characters wayangny [6]. Visual language 'movement' which was originally an expression system outside, through the transfer of space and time, can ultimately be developed through the visual language 'movement' in the current shadow puppet performances [7]. Grouped into three main parts: gestures (body language), transition (transition one movement to the next movement) and war (battle scene). Body language / gesture used, is shown in every scene is a formal body language.

Standard position used in wayang [8]:

1. Movements in the arm at rest also determine the type of puppet characters.

2. Angapurancang arm position, the position of the arm in a quieter character type. Anjujur arm position is the position of the arm similar to angapurancang but this arm position, freer than angapurancang position. In anjujur arm position is straight down, in position to two sprigs pointing anjujur not in a position at the plug.

3. Mathentheng position is a position on one of the arms are in the curve of the hips, with pinchers plugged in debog. Body language is used by all types of puppet characters, both mild-mannered figure, character or figure dashing rough character. Variations of these 
positions typically used for those who have stubborn character or characters that are difficult to compromise.

4. Mathentheng to another version, the basic movements to start running. Kadhak unfortunate position is the basic position that is required for movement run, walk, fly or fight. Kerik is the unfortunate position of body language to express defiance, while other variations both hands placed on the waist, a gesture body language to get ready to attack.

5. Makidhupuh position is a unique body language to position puppet sitting cross-legged or sit cross-legged while walking, occurs when a character in the moving position (knees while walking) or makidhupuh position while worshiping.
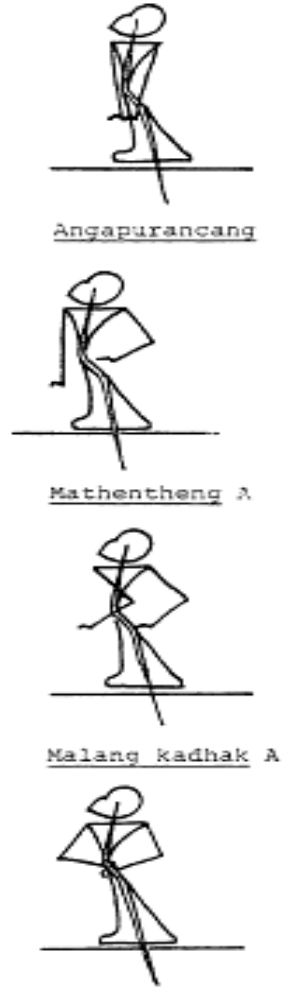

Malang kerik 3
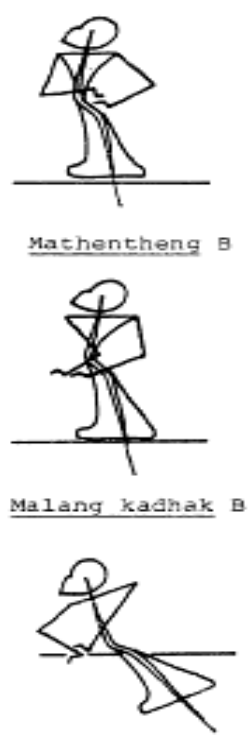

Makianipuh

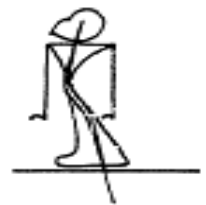

Anju iax

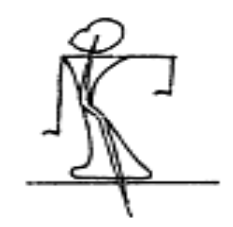

Mathentherg

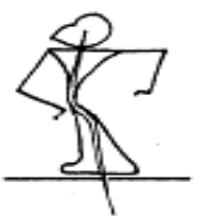

Malang kerik A

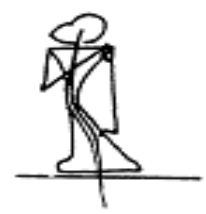

Kingkin

Figure 1. Puppet' Movements (Roger Long, 1979)

In connection with the production code, Henrik Gottlieb (2007) suggested that language as a "communicative communication system that works through a combination of sensory signs"; The text as "a combination of signs that carry sensory communicative intentions"; and Tranposisi as "any process, or product thereof, in which the combination of signs that carry sensory communicative intention replaced by another combination that reflects, or inspired by, the original entity"; thus the creative transposition top marks in a medium to be consistently changed with the shift matrix semiotics. [9] 
This study aims to identify transposition creative 'movement' puppets in 'Setan Jawa' Film based on actor's gestural, which were the novelty of the research is that the combination of signs that carry sensory communicative intention did not in context of replacing, but transpose from puppet's movement as static medium, into 'movement' in mobile-image that visualize on Film. The research has specific area into kinestethic and gestural context as fluid matter ('movement'); positioning as the converted cultural code, which is then mapped into the category of intersemiotika involving elements of nonverbal (deverbalisasi) is supersemiotika - the meaning conveyed more than two channel; picture and movement.

\section{METHOD}

This study was about visual narrative using case study approach [10]. Visual narrative in this study will be adapted from puppet narrative, especially Pathet Nem, which is the construction of the visual of this part develop from the beginning of the story (exposition) [11] — childhood of the main character of 'Setan Jawa' and/or the beginning of dilemma before climax (complication). The data collected is the data related to 'Setan Jawa' Film, as well as additional data for the study were obtained from the literature that support. The data needed for the analysis of the relation of meaning in this study will include reference data and visual data. Visual data gained from the documentation of a 'Setan Jawa' Film. The reference data is a variety of research that has sliced similarity with the object of research to be a reference of research, especially in determining the methodological and theoretical framework of this research. Source reference in documentation analysis will also determine the position of research related to the determination of the identification of problems and research objectives, the data collection will be done on an ongoing basis according to research data.

\section{RESULT AND DISCUSSION}

\subsection{Transposition of Movement' Puppets on 'Setan Jawa' Film}

The creative transposition results analysis of puppet's movement in 'Setan Jawa' Film drawn from some important scenes in the narrative of 'Setan Jawa': the first scene (the birth of 'Setan Jawa') as well as the beginning scene to a climax (Asih Mother reject Setio's proposing).

Table 3.1 Transposition Puppet's Movement on 'Setan Jawa' Film

\begin{tabular}{|l|l|l|l|}
\hline \multicolumn{3}{|c|}{ Puppet's Movement } \\
Malang, \\
Malang \\
Kerik
\end{tabular}




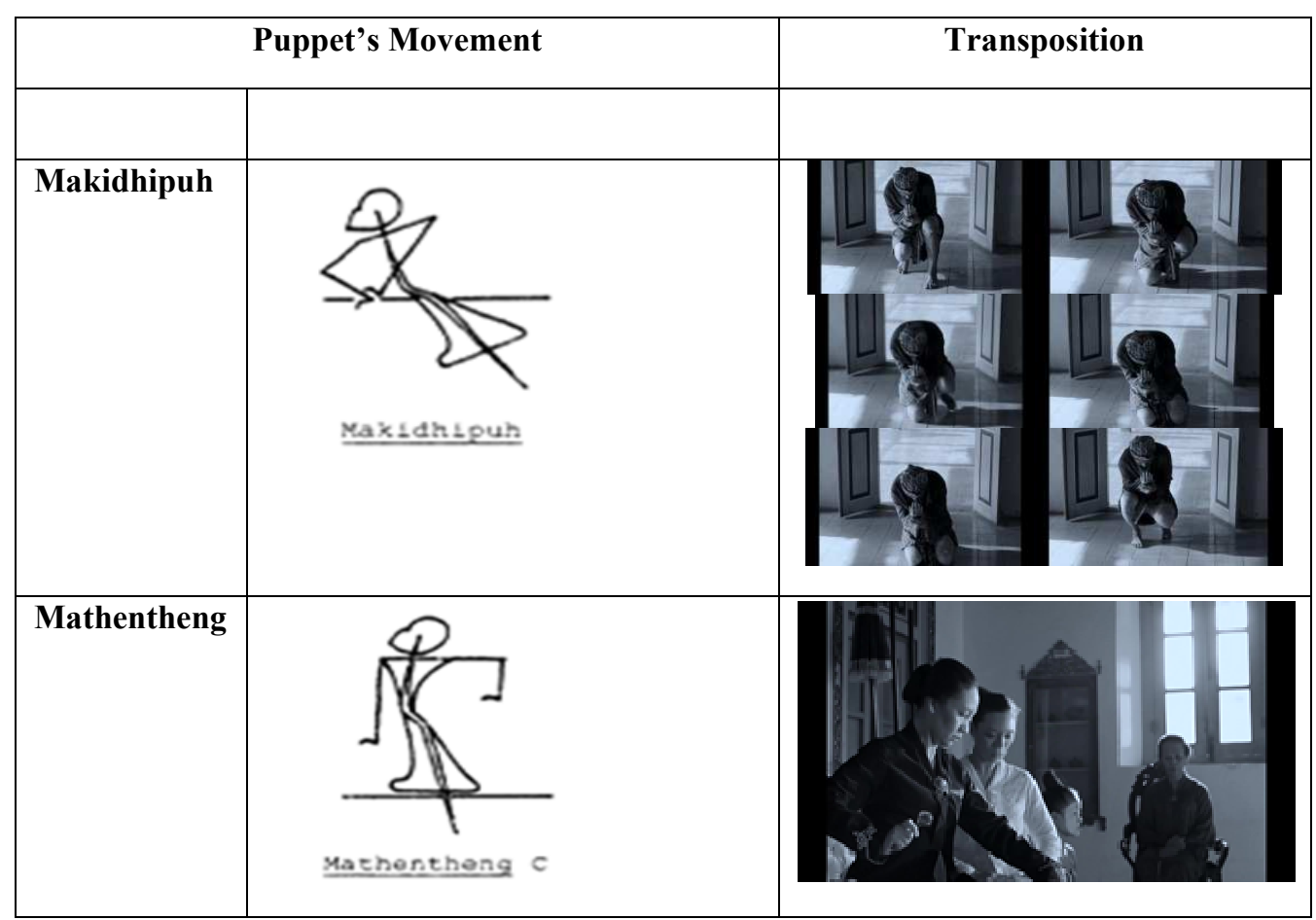

Source of Visual Data: Film 'Setan Jawa' Garin Nugroho (2017)

\subsection{Analysis and Discussion}

Identification transposition of movement puppet in 'Setan Jawa Film, can be identified presence of some typical positions as follows:

- Makidhupuh position are visualized by Setio to sit cross-legged and sitting cross-legged while walking

- Position mathentheng are visualized by the mother with one arm is in the curve of the hip (right arm), varied with the unfortunate position of Kerik which is a body language to express defiance and is typically used for those who have stubborn character or characters that are difficult to compromise.

- Kadhak position adapted in Setan Jawa's gesture, that is visualized through a shadow on the wall (similar to the effects of blencong), is the basic position for movement fights

In The Presentation of Self in Everyday Life (1959), Goffman outlines a conceptual framework in which every opportunity to-face interaction can be interpreted as a theater performance. He expanded the ideas of Kenneth Burke, who pioneered the approach 'tis tic drama', which in turn paved the way for the concept of dramaturgy Goffman to create their own. Goffman believes the idea that life is like a game that never ends where everyone is an actor, and when we are born, we were driven to a stage called everyday life, and that socialization of ours consists of learning how to play the role assigned from others, He uses the metaphor of the theater on the stage, the actors and the audience to observe and analyze the subtleties of social interaction. [12]

In dramaturgical concept of "self" consists of various parts that people play, and the main purpose is to bring together social actors themselves are different in different ways that create and maintain a special impression to their different audiences. Referring to Goffman, creative 
transposition happens in 'Setan Jawa' Film coined the phrase 'impression management', which at this stage applies the mark mechanism to present themselves to others; to construct a general assumption about the character and personality of a person based on physical or ethnic person.[13]

Creative transposition puppet's movements in 'Setan Jawa' Film also represent the different social status of each character. Intersemiotic potentially opens up a space for creative transposition, the transmutation of cultural codes in the image in the image of the film in layers deeper philosophical study. [14] . In 'Setan Jawa' Film, the message and the meaning is read through the visual elements of the subtitles that are constructed by the diversity of use of the medium, as well as films of other Garin Nugroho, one of which is Opera Jawa. [15] Each 'movement' that has been transposed on puppet show that the way we act in life is never constant; no matter what, how 'self' socializing always influenced by where a room where someone is, with whom together, and when to be there. Goffman, adapting Burke, stated that in social interaction, all of 'self' is an actor and the world is a stage.

The result's research assumes that Roger Long (1979)'s research study have possibilities in being several base of puppet's movement to transpose creatively on mobile-section and/or movement-image in film. However, the signs are woven into an intersemiotic process certainly can't be separated away from the grip of puppet's movement, or their pakem [16], which represents 'self' culture of Java on a variety of fabric of social relationships encountered in real life, that one of the roots comes down to the principles of harmony and respect that has become characteristic of the personality of the Javanese. [17] This means, that the creative transposition 'movement' 'Setan Jawa' Film should not forget the 'movement' well as the context of the actual-image and /or concept that is transcendent and imaginary [18] in relation to the transcendent and immanentof the personalities of Java [19]

\section{CONCLUSION}

Puppet's movements shows a conceptual description of 'self' them as Javanese illustrated in phrases according to their expression. In the case of appreciation of the 'self' in real life, the subject of implementing what they interpreted as characteristic of 'self' respectively into attitudes and daily behavior, one of which is manifested through gestures.In the film, the emergence of transposition creatively generate meaning by modification area, which is also a means to adapt the placement of the source language in a new context for a particular purpose, subversion of verbal language, an inter-semiotic' process, which refers to the operation of metalinguistic the direction in which the character of linguistic been moved or changed creatively into elements and non-linguistic code. However, further research is needed as an indepth study in the area of 'movement' as a code in the film that define a certain cultural model; in this case, the movement' code on 'Setan Jawa' Film as medium discourse on cultural identity of Javanese's ethnicity.

\section{REFERENCES}

[1]. G. Deleuze. Cinema 1 The Movement-Image. Minneapolis: University of Minnesota Press, 1986.

[2]. B. Sugiharto. (ed.) Untuk Apa Seni?. Bandung: Matahari, 2013.

[3]. S. Hall. "The Question of Cultural IdentityIn Modernity and Its Futures". Cambridge : Polity Press in association with the Open University, Volume Understanding Modern Societies : An Introduction, pp. 277-280, 1992. 
[4]. U. Eco. Teori Semiotika, Signifikasi Komunikasi, Teori Kode, serta Teori Produksi Tanda. Bantul: Penerbit Kreasi Wacana, 2009.

[5]. C. Mukerji. "The Cultural Power of Tacit Knowledge: Inarticulacy and Bourdieu's Habitus". American Journal of Cultural Sociology Vol 2, pp. 348-375, 2014.

[6]. T. Haryadi, Irfansyah, I. Santosa. "Implementasi Teknik Sabetan Melalui Kinect (Studi Kasus Pengenalan Gerak Wayang Kulit Tokoh Pandawa)", Techno.COM, Vol. 12, No. 1, Februari 2013, pp. 51-64, 2013.

[7]. Ismurdyahwati. "Kajian Bahasa Rupa Berdasar Rekaman Video Pergelaran Wayang Kulit Purwa dalam Lakon 'Parta Krama'”, J. Vis. Art. ITB, Vol. 1 D, No. 3, 2007, pp. 364-390, 2007.

[8]. R. Long. The Movement System in Javanese Wayang Kulit in Relation to Puppet Shadow Type. Ph.D., University of Hawaii, Lampiran C, 1979.

[9]. H. Gottlieb. "Multidimensional translation: Semantics turned semiotics." In S. Nauert \& H Gerzymisch-Arbogast (Eds.), Proceedings of the Marie Curie Euroconferences MuTra: Challenges of multidimensional translation, [Online] EU-High-Level Scientific Conference Series, pp. 1-29, 2007.

[10].Akimoto, T. \& Ogata, T. "A consideration of the elements for narrative generation and a trial of integrated narrative generation system", Proc. of the 7th NLPKE, pp. 369-377, 2011.

[11].Kayam, U.Kelir Tanpa Batas. Yogyakarta: Gama media, 2001.

[12].E. Goffman. The Presentation of Self in Everyday Life, London: Penguin Group, 1959.

[13].E-Chou Wu. "Intersemiotic Translation and Film Adaptation."'In Providence Forum: Language and Humanities Vol. VIII, No.1 (December), 2014.

[14].R. Belasunda, et al. "Hibriditas Medium pada Film Opera Jawa Karya Garin Nugroho sebagai Sebuah Dekonstruksi". ITB J. Vis. Art \& Des, Vol. 6, No. 2, 2014, 108-129 Received July 2nd, 2012, Revised September 27th, 2013, Accepted for publication January 16th, 2014, ISSN: 19783078, DOI: 10.5614/itbj.vad.2014.6.2.3, 2014.

[15].Irfansyah and P. Sunarto. "Kreativitas Kode Visual Golek Asep Sunandar Sunarya dalam Media TV". Wimba, Jurnal Komunikasi Visual \& Multimedia, Vol. 5 No. 1, 2013.

[16].B. Susetyo, DP. "Konsep Self dan Penghayatan Self Orang Jawa". Psikodimensia Vol. 13 No.1, Januari - Juni 2014, pp. 47 - 59, 2014

[17].Hagin, B. "Inverted Identification: Bergson And Phenomenology In Deleuze's Cinema Books".New Review of Film and Television Studies, ISSN: 1740-0309 (Print) 1740-7923 (Online), DOI: 10.1080/17400309.2013.779794, 2013.

[18].Casper, M. O., dkk. "The Movement-Image Compatibility Effect: Embodiment Theory Interpretations of Motor Resonance With Digitized Photographs,Drawings, and Paintings". Frontiers in Psychology,10 June 2018, Volume 9, DOI: 10.3389/fpsyg.2018.00991, Article 991, 2018.

[19].K. Saddhono, "Cultural and Social Change of Foreign Students in Indonesia: The Influence of Javanese Culture in Teaching Indonesian to Speakers of Other Languages (TISOL)," in IOP Conference Series: Earth and Environmental Science, 2018, vol. 126, no. 1. 